\title{
Moving metals III: Possible origins for copper in Bronze Age Denmark based on lead isotopes and geochemistry
}

Melheim, L., L. Grandin, P-O. Persson, K. Billström, Z. Stos-Gale, J. Ling, A. Williams, I. Angelini, C. Canovaro, E. Hjärthner-Holdar \& K. Kristiansen

\begin{abstract}
This article presents the results of a comprehensive provenance study based on a combined geochemical-isotopic and archaeological approach, comprising 98 analyses of 97 copper-alloy objects from the Danish Bronze Age. When it comes to the question of the origin of the metal, our interpretations diverge somewhat from earlier established theories about the origin of copper imported to Denmark, which mainly pointed to Central and Eastern Europe. Clear geochronological patterns in the Danish dataset are interpreted as being due to shifts in ore sources; reflecting varying areas of origin as well as the utilization of varying ore types. This again relates to shifting trade networks/suppliers and shifting technological trends. Plausible sources for Danish copper-alloys identified in the current study are ore regions in the British Isles, Alpine ore districts in Italy and Austria, as well as ore regions in the western part of the Mediterranean and to some degree the Slovak Carpathians. The comparison includes hundreds of recently published lead isotope data for ores in Slovakia, the Iberian Peninsula and the Italian and Austrian Alps.
\end{abstract}

Key-words: Denmark, Bronze Age copper-alloys, lead isotopes, trace elements, reuse of samples, provenance of copper, exchange networks.

\section{Introduction}

This article presents the results of a provenance study of $97 \mathrm{Cu}$-based objects from Denmark, aiming, among other things, at understanding Scandinavia's role in the European exchange networks (Kristiansen, 2013). The study combines trace element analysis with lead isotope analysis. A combined approach is currently the most useful tool when trying to identify copper ore sources. While lead isotope ratios may indicate the age and origin of the ore, element composition characterizes which type of ore the copper derived from. Apart from limited lead isotope studies of singular objects (Klassen and Stürup, 2001; Kresten, 2005; Pernicka, 2010; Schwab et al., 2010), the methodology has only recently been applied more widely in analyses of Scandinavian prehistoric metalwork. While the provenance ascriptions of the current study largely overlap with recent studies of Swedish bronzes conducted by Ling et al. $(2013,2014)$ and Vandkilde $(2017)$, differences between these two regions of Scandinavia may also be noted.

Given that the total number of Bronze Age metal finds in Denmark amounts to an unspecified 5-digit number, it is clear that the current study can only represent a point of departure for more targeted chronological and regional studies. Despite this, the results can be used to go more in-depth on certain aspects of Danish metalwork and metal consumption, since included in the study are some of the finest bronze finds from Denmark. Moreover, the broad chronological scope represents a new approach compared to previous provenance studies carried out in Scandinavia, focusing first and foremost on early metal-using periods (Cullberg, 1968; Junghans et al., 1968, 1974; Klassen, 2000; Krause, 2003; Vandkilde, 1996, 1998; for exceptions, see Liversage and Northover, 1998; Liversage, 2000).

\section{Background for the study}

Denmark is one of the richest regions in Bronze Age Europe in terms of retrieved metalwork. This remains a paradox, since apart from Greenland, present-day Denmark is completely lacking natural copper-bearing ore deposits and would have had to depend totally on metal imported from other areas throughout the Bronze Age. The origin of the metals used to produce the distinguished Nordic 
metalwork has been an unresolved problem. In the formative years of scientific archaeology, it was presupposed that all Bronze Age copper had been imported to Scandinavia from Continental Europe (e.g. Montelius, 1885), and during the following century provenance ascriptions were biased toward Central and Eastern Europe (e.g. Kristiansen, 1998; Thrane, 1975). Interpretations have been circumstantial, resting in the final analysis on typology, artefact distribution patterns and hypothetical matches with Bronze Age mines. A theory of indigenous mining on the Scandinavian Peninsula (e.g. Melheim, 2009, 2015; Prescott, 2006), suggested that populations in Denmark might have depended on copper from ore sources in Norway or Sweden. However, in the recently published studies of c. 70 Swedish metal objects and casting debris (Ling et al., 2013, 2014), all analyses (with one exception - a slag) were interpreted as being of non-local origin. ${ }^{1}$

\section{Lead isotopes as provenance indicators}

The applied methodological approach broadly follows Ling et al. (2014). The fundamental aspects of lead isotope (LI) tracing are well-known and we shall only briefly address some source-critical factors of relevance for this study (for a broader discussion of the method's applicability in archaeology, see e.g. Albarède et al., 2012; Baron et al., 2013; Gale, 2001; Hauptmann, 2009; Northover et al., 2001; Rehren and Pernicka, 2008; Stos-Gale and Gale, 2009). The use of LI for provenancing is based on the assumption that the lead component in bronze (usually <1\%), originates from the copper ore used in production. Occasionally, lead was added during the metallurgical processes, and when added, generally in concentrations well above $1 \%$. Tin, the other major component of bronze, is usually not associated with appreciable amounts of lead in nature, and the number of known ore sources of $\mathrm{Sn}$ is limited in relation to the number of $\mathrm{Pb}$-bearing copper ores known to have been exploited during the Bronze Age in Europe.

Several factors may complicate the interpretation of the source of lead, and the foremost are the wide ranges of isotopic compositions often noted within a certain ore district and the isotopic overlap between data from different districts. It must also be noted that if ores formed at the same time but acquired lead from source rocks having contrasting isotopic characteristics, then this may result in misleading ore lead model ages. Further complexities during the stage of interpretation of provenance areas may arise if manual mixing of ores from different districts took place, or if previously cast objects were re-melted. Linear patterns do occasionally show up when data are plotted in $\mathrm{Pb}-\mathrm{Pb}$ diagrams. Such patterns could be explained in two different ways; either as a result of physical mixing of isotopically different source material at the time of smelting or casting, or, in-situ decay of uranium and thorium which took place between the time of ore formation and mining (producing additional amounts of ${ }^{206} \mathrm{~Pb},{ }^{207} \mathrm{~Pb}$ and ${ }^{208} \mathrm{~Pb}$ ).

\section{Material and methods}

The artefacts sampled for the current data-set cover the entire Nordic Bronze Age and most parts of Denmark, and also include two Late Neolithic axes (Figs. 1-2, for details see Table 1, Supplementary table 1). The periodization builds on well-established typo-chronologies (Montelius, 1885), and is anchored in absolute chronology (Olsen et al., 2011; Vandkilde et al., 1996) (Table 2). The original assemblage of 77 samples comprised high-quality objects from hoard finds like Late Neolithic (23501700 BCE) Store Heddinge, Early Bronze Age (1700-1100 BCE) Dystrupgård, Torsted, Bagterp,

\footnotetext{
${ }^{1}$ While copper ores on the European Continent were dominantly formed in the 400-100 million years (Ma) interval, many of the $\mathrm{Cu}$ ores in Sweden have ages around $1900 \mathrm{Ma}$, belonging to the Precambrian basement. A large age contrast means that lead isotope ratios are very different from each other, and it is easy to discriminate between e.g. hypothetical origins in Europe and Bergslagen in Sweden. Other copper-bearing ore deposits in Scandinavia with younger ages exist; e.g. c. 1200 Ma old deposits in Dalsland in southwestern Sweden (Alm et al., 1997), c. 500-400 Ma old deposits in the Caledonian mountain range that straddles the border between Norway and Sweden (Grenne et al., 1999), and c. 300 Ma deposits in the Oslo field (Grenne et al., 1999). No clear matches with any of these ores were, however, obtained in the Swedish study.
} 
Vognserup Enge and Røjlemose, and Late Bronze Age (1100-500 BCE) Ejsdrup, Kostrøde, Flø, Lysemosegård and Antvortskov. Also included were iconic finds like the period II octagonal-hilted sword from Ramløse. The remaining 21 analyses come from a targeted regional study from Thisted and Randers in northern Jutland, focusing on swords and bracelets from Early Bronze Age barrow burials.

The 77 samples reused for LI analysis were kindly provided by Peter Northover, responsible for the analytical undertakings and the preparation of the samples for the earlier electron microprobe analysis (EPMA). Samples of millimetre-size mounted several together in resin were ground and polished. The original analyses were made using a CAMEBAX instrument at the Department of Materials, Oxford University. Wave length dispersive (WDS) analyses were made at three different points measuring 50 by 50 microns at an accelerating voltage of $25 \mathrm{kV}$ and an absorbed current of $30 \mathrm{nA}$. Pure element standards were used and data were ZAF corrected.

A few of the originally mounted samples had not been analysed in the first study. These samples were included in the present study following the same analytical procedure, along with the 21 new samples from northern Jutland. Subsequently, an optical microscope with polarised reflected light was used in order to define the structure and texture and prepare for succeeding EPMA using the JEOL JXA$8530 \mathrm{~F}$ at the Centre for Experimental Mineralogy, Petrology and Geochemistry at Uppsala University. WDS analysis was made as point analyses in separate phases as well as in area scans (50 by 50 microns). The scans were distributed along traverses to attain the bulk chemical composition of the alloy. Due to the common heterogeneity of copper alloys, exhibiting dendritic textures, multiple area scans were made and mean values calculated. Operating conditions during runs involved an acceleration voltage of $20 \mathrm{kV}$ and an electron beam current of $20 \mathrm{nA}$. The obtained analytical data were related to standards (oxides, sulphides, metals) and ZAF corrected. Furthermore, the detection limits for most elements (see Supplementary table 2) were improved with the currently used instrument; in particular for As, avoiding the interference with $\mathrm{Pb}$ (see also Northover, 1996b).

Since two types of analytical instruments (CAMEBAX and JEOL JXA-8530 F) were involved in producing the element composition data-set, some samples for which results were initially presented by Northover and co-workers (Northover, 1996a; Liversage and Northover, 1998; Liversage 2000) were re-analysed by the current team in order to be able to compare the results. Generally, the agreement between the old and the new analyses was good (Supplementary table 2), but in a few cases discrepancies were larger. This is potentially due to heterogeneous material in some samples. The new analyses form the basis for interpretations (Supplementary table 1).

Following the microprobe analyses, suitable bronze pieces were digested in hot $6 \mathrm{M} \mathrm{HNO}_{3}$ in order to prepare them for LI analysis. Prior to dissolution they were leached for a few minutes in $\mathrm{HNO}_{3}$ at room temperature in order to remove possible surface contamination and some of the alteration products such as malachite. After dissolution the lead was extracted by means of anion exchange column chemistry. The isotope measurements were performed at the Laboratory for Isotope Geology at the Swedish Museum of Natural History in Stockholm with a Multi-Collector Inductively Coupled Plasma Mass Spectrometer (MC-ICP-MS) of the type Micromass Isoprobe. The mass bias correction was made by adding thallium to the sample. Details are described in e.g. de Ignacio et al. (2006). The total error (external reproducibility) for reported $\mathrm{Pb}$ isotope compositions of unknowns is estimated to be $\pm 0.10 \%$ or lower.

\section{Results and main trends}

\subsection{Chemical compositions of the analysed bronzes}

All the analysed artefacts are tin-bronzes. A variation in Sn-content that is related to chronology can be distinguished with generally highest $\mathrm{Sn}$ in artefacts mainly from period II, followed by those from period III. Artefacts from period I as well as periods IV to VI tend to have lower Sn-contents (Fig. 3_1). Given the generally low concentrations of $\mathrm{Pb}$ (Fig. 3_2), it is not likely that lead was 
intentionally added to any large degree. Only a few samples have Pb-contents (up to $5.5 \%$ ), that might be due to intentional addition.

The obtained element data typically show variable concentrations of certain trace elements, whereas the lack or presence of some other elements suggests that different ore types were processed during the Bronze Age. The metal groups defined by David Liversage (2000) are referred to when applicable. Although there are some intra-period differences, some general trends related to chronology can be distinguished. The two analysed axes from the Late Neolithic are dissimilar but both contain As, Sb and Ag at levels observed in other Scandinavian samples from this period (e.g. Vandkilde, 1996:191122), reflecting fahlore sources. The majority of the artefacts from period Ia also contain trace elements generally related to fahlores, yet at lower concentrations and also including Ni. The artefacts from period $\mathrm{Ib}$ appear to be more heterogeneous, however, one group of artefacts with uniform trace element concentration of $\mathrm{Ni}$ and As may indicate the use of either $\mathrm{Cu}$-sulphide ores (e.g. chalcopyrite) or oxidised ores. The remaining artefacts are more heterogeneous in their elemental patterns. Period II artefacts are characterised by $\mathrm{Ni}$ and $\mathrm{As}$ as the main impurities. The same trace elements are present in period III objects, even if in noticeable lower amounts. In period IV, Ni is present as a trace element and fahlore signatures are few or absent. In periods V and VI both fahlore signatures and Ni contents are pronounced. Along with fahlore copper, copper with low impurity patterns are also reflected in the bronzes from periods IV-VI. The occurrence of fahlore signatures in the Late Bronze Age is in accordance with earlier observations made on the basis of Scandinavian finds (Ling et al., 2014; Liversage, 2000:81-86). The same goes for the occasional elevated content of lead (Liversage, 2000:80-84).

\subsection{Lead isotope compositions of the analysed bronzes}

The current data-set exhibits a large range of lead isotopic ratios; with e.g. ${ }^{206} \mathrm{~Pb} /{ }^{204} \mathrm{~Pb}$ ranging from 17.933 to 19.319 . There is no simple pattern where samples from a specific period plot solely within a restricted area in the isotope diagrams, yet data can be provisionally grouped into several loosely defined clusters that can be differentiated as follows (see letters A-E in Fig. 4); a low-radiogenic group $\left({ }^{206} \mathrm{~Pb} / 204 \mathrm{~Pb} \leq 18.10\right.$; group $\left.\mathrm{A}\right)$, a group with high-radiogenic, and yet variable compositions $\left({ }^{206} \mathrm{~Pb} /{ }^{204} \mathrm{~Pb} \geq 18.80\right.$; group $\left.\mathrm{B}\right)$, a group with comparatively low ${ }^{207} \mathrm{~Pb} /{ }^{204} \mathrm{~Pb}(\leq 15.64$; group C), a large group with intermediate isotopic compositions (group D), and finally a group defining a narrow range at the high radiogenic end of the data spectrum (group E).

Broadly speaking, bronzes from Denmark span a similar isotopic interval as defined by Swedish samples (Fig. 5), the distinctions being that the Danish data-set comprises fewer samples at the high radiogenic end, and a significant proportion of low radiogenic samples. With one exception, the most radiogenic samples in the Danish data-set, with ${ }^{206} \mathrm{~Pb} /{ }^{204} \mathrm{~Pb}>18.6$, belong in periods I-II and their lead contents are low. These isotopic compositions are assumed to be influenced by radiogenic lead generated as a result of in situ decay of $\mathrm{U}$ and Th in the ore bodies. Tentatively, linear trends can be identified in the $\mathrm{Pb}-\mathrm{Pb}$ diagrams and their significance will be further discussed below.

In order to be able to identify the geographical origin of the copper, geochemical and isotope characteristics of European ore deposits known to have been exploited in the Bronze Age have been considered. In this respect, it was considered equally important to define possible provenance areas, as ruling out others. With some exceptions, the analysed Danish bronzes are in general not consistent with sources in south-east Europe, like Serbia, Romania, Bulgaria, Greece and Cyprus and only to some degree with sources in the Slovak Carpathians. Our LI data for bronzes rather suggest a dominant origin from three geographical regions, the British Isles, Alpine Europe (districts in Italy and Austria), and the western Mediterranean (Spain and France).

\subsection{Interpretations of chemical and LI analyses in a chronological perspective}

In the following, the provenance of copper in the analysed samples will be discussed on the basis of geochemistry and LI in relation to chronology. Surely, there are outliers with unusual elemental content or odd isotopic composition compared to other artefacts from the same period or from the 
same locality, but focus in the forthcoming text will be on the main patterns. Figure 6 presents an overview of the suggested provenance areas for the copper, and contains a compilation of literature listing reference data from relevant ore districts. Reference $\mathrm{Pb}$ isotope data for ore deposits of relevance are also presented in a series of diagrams (Figs. 9, 10, 11, 12, 13 and 14).

Late Neolithic II (2000-1700 BCE): The two LN II axes included in this study belong to the Store Heddinge hoard. LI of only one axe (\#371) is listed in Supplementary table 1, since the other analysis (\#372) was considered unreliable due to low signals. Despite the high analytical error, it is nearly certain that the copper in $\# 372$ contains comparatively high radiogenic lead $\left.{ }^{206} \mathrm{~Pb} /{ }^{204} \mathrm{~Pb}>18.6\right)$, and hence that it originated from a different ore deposit than \#371. Since the two axes are also chemically different from each other, the idea of different origins must be considered.

The chemical composition of \#372, with high contents of As, Sb and Ag indicates a fahlore origin (Figs. 7 and 8). The combination of a fahlore source and radiogenic lead in \#372 may certainly be compatible with an origin in the Austrian Alps (cf. Stos-Gale, 2017:208; Vandkilde, 2017:142, Fig. 76). Contrary to this, the LI of \#371 does not match the Alpine ores, nor the analysed Ösenringe from this region (Höppner et al., 2005). This axe has lesser impurities, which is in accordance with some other contemporaneous Scandinavian samples, including two previously analysed axes from the same hoard find (Vandkilde, 1996:191-194, 421, 483, 2017: Fig. 84). This general type of metal has been defined as C2D/C5 (Junghans et al., 1968; 1974), or, modified Ösenringe metal (mOe) (Liversage, 1994, 2000). It is traditionally associated with the Únětice culture and is thought to derive from a fahlore source in the Austrian eastern Alps (Liversage, 1994:68; 2000:72). Judging from the presence in the Store Heddinge hoard of axe types and metal types assumed to relate to Insular technocomplexes (Vandkilde, 1996:87-88, 209), a connection to the British Isles or Ireland may be hypothesized. Such a link is further indicated by recent provenance analysis of the Pile hoard, identifying the low impurity copper of an Anglo-Irish axe shape as originating from Alderley Edge in England (Vandkilde, 2017:140-143, Fig. 76; Stos-Gale, 2017:210). The LI of \#371 is consistent with Welsh ores from deposits in Dyfed (Fig. 9). Copa Hill/Cwmystwyth was mined already 2100-1600 BCE (O'Brien, 2015:139-144). But since there is no evidence at present that these mines contained fahlore (Ixer and Budd, 1998), a provenance from Dyfed is unproven, pending a thorough ore analysis programme in that area. Fahlore was mined at Ross Island in Ireland in the period in question, however, the LI ratios of the ores here are quite different from the copper of \#371, as can be seen in Figure 9 (cf. O’Brien, 2004:538-550).

Period I (1700-1500 BCE): The geochemical signatures of the 18 period I objects included in this study (five from period Ia and 13 from period $\mathrm{Ib}$ ), mainly swords and flanged axes (various sub-types), are similar to metal types widely circulating in Europe in the Early Bronze Age. When it comes to provenance, an intra-period division is apparent around $1600 \mathrm{BCE}$.

Four flanged axes dated to period Ia (an axe from Funen, \#343; and three axes \#\#357-9 from the Bondesgårde/Torsted hoard) have chemical signatures corresponding to the metal group $\mathrm{mS}$ (Liversage, 2000:60-63). They contain Sb, Ag, As and Ni (c. 0.15-0.40 \%), indicating a fahlore source. Their similar chemical compositions (Figs. 7 and 8) and quite unusual and distinct LI compositions suggest that the four axes may have been made from the same ingot (Fig. 4 cluster E, Fig. 10). An origin from an east-central European ore source would fit well both with the style and chemical composition of the metalwork, which are typical of the Únětice core area (Melheim and Horn, 2014). Looking at $\mathrm{Pb}$-isotopes and elements in a combined perspective, the Slovak Carpathians is a likely source to the copper in these artefacts. Their LI ratios are fully consistent with copper ores in the Banska Stiavnica region, and in particular the area of Spania Dolina, where there is evidence of mining in the $2^{\text {nd }}$ millennium BC of Sb-rich fahlores as well as primary sulphides (Kušik, 2015; O’Brien, 2015:186-187; Schreiner, 2007). 
With a few exceptions, the majority of analysed metals dated to period $\mathrm{Ib}$ plot in the isotopic cluster C (Fig. 4) and are quite homogeneous when it comes to elemental compositions (Figs. 7 and 8), falling broadly within the AsNi group (Liversage, 2000:14-17).

While two of the three swords from Dystrupgård have Ni and As at levels comparable to many other artefacts from period $\mathrm{Ib}(\# 17618,17622)$, the third sword (\#17623), with lower ${ }^{207} \mathrm{~Pb}$, is different from any other artefact in the current study, lacking $\mathrm{Ni}$ and As but with elevated concentration of both $\mathrm{Fe}$, Co. In addition, it is much lower in $\mathrm{Pb}$ and $\mathrm{Sn}$. Judging from style, technology and context, the swords appear as 'bulk' production. In all likelihood the altogether eight swords of this hoard, although inspired by the Hajdúsámson-Apa metalwork of east-central Europe, derive from a local Danish workshop. However, lacking decoration and surface finish, \#17623 stands out from the other swords, and an interpretation as a model sword is feasible (Melheim and Horn, 2014). If this is true, it is not unlikely that a different alloy and metals with slightly different characteristics were used for the model and the finished swords. While the swords are fully consistent with Great Orme metal isotopically (Figs. 9 and 10), As is somehow low relative to Ni compared to the typical elemental signature of Great Orme metal, however, still plotting within the Great Orme ranges. Based on a combined approach, a common origin from the Great Orme seems reasonable. In this case therefore, style and metal seem to have different origins; metal from the west was transformed into an east-central European stylistic koiné (Vandkilde, 2014).

Another four artefacts in cluster $\mathrm{C}$ are considered to be consistent with ores from the Great Orme. These are the flanged axes (\#\#657, 658) from the Bagterp hoard, a shafthole axe (\#345), and possibly another flanged axe (\#327), although Ag in this axe at $0.25 \%$ is anomalous compared to the bulk chemistry of Great Orme. Isotopically, the metal is also consistent with some copper ores in Cornwall (Rohl and Needham, 1998:62), but an origin from Cornish ores remains hypothetical, since only indirect evidence of prehistoric copper mining has hitherto been identified here (O'Brien, 2015:154155). In addition, the artefact Ni levels are higher than that seen in the limited Cornish ore analyses currently available (Williams, forthcoming).

Interestingly, the flanged axe from Kundby (\#323) has low trace element concentrations and a clearly radiogenic signature with ${ }^{206} \mathrm{~Pb} /{ }^{204} \mathrm{~Pb}$ at 19.183 . This is principally interesting as highly radiogenic values are present in periods I and II in the Swedish data-set (Fig. 5) (Ling et al., 2014). A common observation for all radiogenic data acquired in this study (defining cluster B in Fig. 4) is that they only contain low levels of lead, indicating an origin from ore sources with elevated $\mathrm{Th} / \mathrm{Pb}$ and $\mathrm{U} / \mathrm{Pb}$ ratios. We propose that their LI compositions are controlled by in-situ growth of radiogenic lead, having taken place after the time of ore formation. The axe \#323 is isotopically and chemically consistent with radiogenic ore data from the Great Orme mine. Also another axe (\#322) plots within the radiogenic ores in Great Orme.

The two chisels (\#\#346 and 347) are typologically similar and belong to the same main chemical type, yet have previously been considered to be chronologically divided (from periods Ia and $\mathrm{Ib}$ respectively) (Vandkilde, 1996:211-212) ${ }^{2}$. Both are single finds from unknown find spots. Given that the the chemical and isotopic features are so similar and characteristic of period Ib, we propose that both of them should be dated to period Ib. While the Great Orme mine in Wales isotopically has a very good fit with these artefacts (Figs. 9 and 10), such high Sb levels (0.22-0.25\%) remain anomalous with the known bulk chemistry of Great Orme ores which is usually well below $0.1 \%$ (Williams, 2017). An origin from ore sources in the British Isles is tentatively suggested.

In addition, three artefacts from period Ib have LI compositions consistent with the ores from Spania Dolina: a shafthole axe (\#344) and two flanged axes (\#\#321 and 339). \#321 and 344 are somewhat

\footnotetext{
${ }^{2}$ We base our interpretation on the elemental data for \#\#346 and 347 cited by Northover (1996a:357) and not the SAM data, which seem to be the basis for Vandkilde's division between the two (cf. Vandkilde 1996:489).
} 
different in elemental composition from the other period Ib bronzes, containing $\mathrm{Sb}$ and As. A Mitterberg origin for \#344 is possible (Fig. 10), but seems less likely considering the elevated Sbcontent and the low abundance of fahlores at Mitterberg (Pernicka et al., 2016:22, 29). For \#339, with As and $\mathrm{Ni}$ as main impurities, the Italian eastern Alps is another possible interpretation.

Period II (1500-1300 BCE): Approximately half the samples from period II $(\mathrm{n}=33)$ comes from two sites: Røjlemose $(n=7)$ and Vognserup Enge $(n=10)$. The remaining 16 samples come from a number of different sites. Chemically speaking, the majority of the analysed artefacts from period II have similar geochemistry with $\mathrm{Ni}$ and As as main impurities. Some artefacts, three sword blades (\#\#134, 135 and 5460) and a neck collar (\#137) have Sb in concentrations at c. $0.2 \%$, or higher. The objects from the two hoards are covered by Liversage's AsNi group, but with variations noted at a more detailed level (Fig. 8), indicating that there are sub-groups within the broader picture. Vognserup Enge presents a larger chemical variation compared to Røjlemose.

In terms of LI, the picture is quite complex as quite a few data points plot within the overlapping ore fields of Italy and southern Iberia. In an overall analysis, the bulk of bronzes dated to period II shows best consistency with ores in the Italian eastern Alps, while a smaller group is consistent with ores in southwestern Spain (Fig. 11). However, the considerable LI variability may be indicative of origins from a combination of ore sources. Mixing of ores from several different mines was recently demonstrated in a mineralogical and isotopic investigation of slags from smelting sites in Italy (Addis, 2013; Addis et al., 2016).

The relatively uniform chemical composition characterizing the samples from the Vognserup Enge and Røjlemose hoards urges us to consider whether a common origin of metal within single hoards is conceivable. Vognserup Enge comprises two sets of female jewellery (altogether more than 240 objects). The metalwork is typologically and stylistically homogenous and is thus, from an archaeological viewpoint, likely to represent one or two metal workshops. A common ore source origin for all the 10 analysed objects from Vognserup Enge is however questionable as the LI data are variable, including both the least radiogenic samples of all the Scandinavian analyses (Fig. 4, cluster A), with one ${ }^{206} \mathrm{~Pb} /{ }^{204} \mathrm{~Pb}$ ratio as low as 17.933 , as well as intermediate compositions (cluster $\mathrm{C}$ and $\mathrm{D}$ ). The analytical data may be considered to suggest that the Vognserup Enge hoard contains metal from (at least) two isotopically different sources, with broadly similar chemical characteristics.

Røjlemose is a mixed hoard consisting of tools, weapons and scrap metal (altogether 43 objects) and is, from an archaeological viewpoint, likely to represent metal collected at different occasions, thus potentially deriving from a variety of sources. Fig. 4 shows that data points occur at the radiogenic end (cluster B), the least radiogenic end (cluster A) and in-between (cluster D). If a common origin for the metal is assumed, which is feasible in a chemical perspective, one could imagine that the variability of the LI is controlled by a single, common source with variable proportions of $\mathrm{Pb}, \mathrm{U}$ and $\mathrm{Th}$. As all Røjlemose samples indeed plot on a straight line (1-1' trend in Fig. 4) with a slope consistent with an approximative $300 \mathrm{Ma}$ isochron, one cannot rule out this explanation. An opposing interpretation is that the linear trend represents mixing of metal from (two main) isotopically different sources. Judging from isotope data, one cannot distinguish between these interpretations. In light of the homogenous chemistry, it appears most likely that the metal derived from one or two dominant, and geochemically homogeneous sources (but, yet, with variable $\mathrm{U} / \mathrm{Pb}$ and $\mathrm{Th} / \mathrm{Pb}$ concentration ratios).

On the basis of a careful evaluation of the isotopic and elemental data from both hoards, two main areas of origin may be hypothesized. For the low-radiogenic samples defining cluster A in Figure 4 (Vognserup \#\#520, 522, Røjlemose \#638) as well as several other samples (Vognserup \#\#521, 524, 525, Røjlemose \#\#635, 636, 639), an origin from ores in the Italian eastern Alps seems reasonable (Fig. 11). Most of these fit the ores of the Alto Adige, Trentino and Veneto field in the southern Alps (South Alpine AATV) while three objects are consistent with the Valsugana volcanogenic massive sulphide field (Valsugana VMS) (as defined in Artioli et al., 2016). Another group of bronzes from these hoards (Vognserup \#\#526, 527, 528, 529, Røjlemose \#\#637, 640) matches ores in southern 
Iberia (Fig. 11). With two exceptions, thus, all analyses seem to point toward ore regions in the Italian eastern Alps or southern Iberia. One sickle from Røjlemose (\#641) is isotopically and chemically consistent with Slovakian ores, and one tutulus from Vognserup (\#523) with the Great Orme. Interestingly, in terms of provenance ascriptions, there are two groupings among the analysed pieces of jewellery from the Vognserup Enge hoard: all but one sheet tube being attributed to ores in southern Spain, while the majority of the tutuli show a good match with ores in the Italian eastern Alps. Thus, within single hoards sets of jewellery may be argued to have singular origins.

In addition to the nine artefacts from Røjlemose and Vognserup, another seven period II objects may be attributed to the Italian eastern Alps (\#\#129, 134, 135, 136, 137, 5115 (knife), 5460). On the basis of chemical, typological and contextual overlap with \#129, an origin in the Italian Alps is suggested also for \#128, although southern Iberia seems equally plausible judging from the LI. A sword (\#5567) stands out with a marked content of $\mathrm{Ag}$ of $0.3 \%$ and $\mathrm{Pb}$ of $0.65 \%$ (lacking $\mathrm{Ni}$ and $\mathrm{As}$ ), on a level unprecedented amongst previously analysed artefacts from Denmark irrespective of chronology. The isotope data suggest a south Iberian origin. Two more objects, the latter lacking elemental data can be ascribed to southern Iberia (\#\#139, 5078).

Another two bronzes (\#\#530, 538) show good consistency isotopically with ores from the Great Orme (Fig. 11). The Sb content in the collar (\#530) is somewhat higher than typical Great Orme copper, but within the analytical error. The wire coil (\#538) has low trace element levels, but an unusually high $\mathrm{Pb}$-content $(5.5 \mathrm{wt} \%)$. This might indicate that lead was intentionally added during casting. However, at the Great Orme, high levels of lead in copper smelted in the Bronze Age are known to be the result of veins of lead and copper ores running next to each other (Williams, 2014, 2017). A sword (\#140) falls within the ranges of Great Orme copper ores, but is consistent also with the Slovak Carpathians.

Two of the analysed bronzes, a sword (\#5538) and a spiral ring (\#133) have highly radiogenic and, to this group, exceptional lead isotope ratios which are consistent with ores from Mitterberg.

Period III (1300-1100 BCE): The data-set mainly consists of sword samples from Jutland ( $\mathrm{n}=18$, including two samples (\#5023 A and B) from one sword (hilt and blade), and \#5233 which belongs in either period III or IV). Basically, the chemistry fits the general AsNi pattern (Figs. 7 and 8), but with varying proportions of $\mathrm{Ni}$ and $\mathrm{As}-\mathrm{a}$ feature replicated in other Scandinavian data-sets from the same period (see Ling et al., 2014; Liversage, 2000; Melheim, 2015). Yet, there is a tendency to lower element concentrations compared to period II.

The period III objects plot within generally the same LI ranges as the period II samples, but with a more limited spread ranging from intermediate to low ${ }^{206} \mathrm{~Pb} /{ }^{204} \mathrm{~Pb}$ isotope ratios, yet with relatively high ${ }^{207} \mathrm{~Pb} /{ }^{204} \mathrm{~Pb}$ and ${ }^{208} \mathrm{~Pb} /{ }^{204} \mathrm{~Pb}$ (Fig. 4). The isotopic similarity between period II and III samples may suggest a broadly common origin for the copper (Fig. 12). Another twelve bronzes (\#\#138, 141, 660, 5002, 5027, 5074, 5075, 5147, 5237, 5084, 5115 (sword), 5129) are isotopically consistent with ores of the South Alpine AATV and slags from the Italian eastern Alps near Trento (Addis, 2013; Artioli et al., 2014, 2016) and in an overall approach another five objects - swords of various typologies (\#\#142, $659,5077,5023 \mathrm{~B}, 5233$ ) may also be considered to fit into this pattern, although southern Iberia is also possible judging from the LI. When it comes to \#142 - a Naue II sword - an east-central European origin would be expected on the basis of the style of the metalwork, again showing that ore source and typology do not necessarily overlap.

One of the swords (\#5023) merits further consideration. The blade and the hilt of this sword were analysed separately, and it turned out that these parts (A, B in Table 1) are somehow different both in terms of LI and chemistry. The blade of this full-hilted sword seems to be made of different copper from its hilt. While the metal from the hilt is, as noted above, consistent with ores in the Italian Alps (even if it falls in the area with some overlap with Spain), the blade (\#5023A) is isotopically consistent with the copper ores from the Calabona mine in Sassari, Sardinia. Corresponding results, with 
different origins of metal in hilt and blade, have been obtained in previous analyses of Scandinavian swords (Bunnefeld, 2016:164-169; Liversage, 2000:19-20, 103-104; Melheim, 2015:70).

Period IV (1100-900 BCE): The analytical data-set from period IV ( $\mathrm{n}=7)$ is limited, and yet shows quite variable elemental chemistry (Figs. 7 and 8). The main feature among the analysed artefacts is the low content of impurities (see also periods V and VI). Generally, the Ni content is also lower compared to artefacts from periods II-III. The typical NS metal (originating from fahlores), that previously has been documented to replace the AsNi metal in Danish (Liversage, 2000:33, 39-45) and Swedish (Ling et al., 2014) artefacts from this period, are observed only in a few of the currently analysed artefacts.

At the scale of individual objects, the three objects from the Ejsdrup hoard present a variation from very pure (\#\#654-5) to low concentrations of fahlore-indicative elements (\#656). On the basis of typology, the two Fuchstadt type cups of the Ejsdrup hoard (\#\#654-5) and the sieve or strainer from Kostræde (\#531); with very low, or zero contents of impurities have previously been considered import objects from east-central Europe, i.e. present-day Germany or Hungary (Thrane, 1975:136, 144). The remaining samples from period IV are disparate in various ways; with one Sn concentration (\#653, a fibula) as high as $22 \mathrm{wt} \%$, although the low total sum indicates that this sample was severely oxidized.

The majority of the bronzes dated to period IV has lead isotope data similar to those obtained for period II and III samples, being principally consistent with the South Alpine AATV ores in the Italian eastern Alps (\#\#531, 654, 655, 656, 661). This goes also for \#653, although Spain, Jaen, is another possibility (Fig. 13). Interestingly, the imported objects (Ejsdrup and Kostræde) show consistency with Italian ores, against previous provenance ascriptions pointing toward east-central Europe.

Together with a recent analysis identifying the Kostræde sieve's contents as Eurasian grape (McGovern et al., 2013), this seems to indicate that a broader network of producers and consumers were involved in the production of raw materials. The axe from Hårløse (\#143) is a one-off that seems to originate from an ore with significant $\mathrm{U} / \mathrm{Pb}$ and $\mathrm{Th} / \mathrm{Pb}$ ratios (Fig. 4); its $\mathrm{Pb}$-content is below the detection limit for EPMA. It is generally low in impurities (cf. Liversage, 2000:22). The LI ratios are consistent with the ores from Mitterberg in the Austrian Alps, where low impurity copper do occur (Pernicka et al., 2016).

Period V-VI (900-500 BCE): The majority of samples comes from three hoards: Flø, Lysemosegård (period V) and Antvortskov (period VI). The geochemical data for periods V $(n=10)$ and VI $(n=10)$ are similar and show a binary pattern typical of the Late Bronze Age. There are two types of metals: one type has a fahlore character (combination of traces of $\mathrm{As}, \mathrm{Sb}$ and $\mathrm{Ag}$ ) as well as elevated Ni-contents, the other type is low in impurities (Figs. 7 and 8). The Pb-contents are on average higher than in earlier periods. Characteristic fahlore signatures are noted in \#\#631, 632, 634 from Lysemosegård, \#\#532, 533, 534 from Flø, and \#\#648, 649, 650 and 651 from Antvortskov, whereas the remaining hoard samples generally show low levels of trace elements.

Looking at the pattern of LI seen in Figure 14, it is striking that the majority of samples from periods V-VI plot quite differently from previous periods. The LI indicate intermediate values and a moderate spread in all three Pb-ratios, except for one of the Flø samples (\#537). Noteworthy, the analyses from all three hoards give the impression of forming trends with steep slopes and one example is the 2-2' trend outlined for the Antvortskov samples (Fig. 4). The steep slopes rule out that they are isochrones, but it is obvious that the levels of fahlore elements, such as $\mathrm{Sb}$ and $\mathrm{Ag}$, in period V and VI samples cover a basically continuous range from almost zero to percentage levels when plotted in appropriate bivariate diagrams (not shown). In other words, in a geochemical perspective the hypothetical trends could be mixing lines connecting two metal sources, one of them a fahlore and the other a $\mathrm{Cu}$-sulphide ore. The LI ratios are, however, not correlated with the concentrations of these elements, but it is clear that the bronzes with fahlore and $\mathrm{Cu}$-sulphide ore characteristics plot quite closely together in the 
isotope diagrams. This may suggest that the copper derived from chemically different yet isotopically similar ore formations either within the same region, or, from different areas.

Five samples from Flø (\#\#532-535, 537) have quite high Sn-content (around 8-10\%) for this point in time. Similarly high tin values are found in period VI-samples, two torcs of the Wendel type (\#\#646, 647) from Antvortskov and two singular finds $(\# 642,645)$. Another noteworthy feature is the high $\mathrm{Pb}$ in some samples, sometimes concurring with high Sn but not always.

Interestingly, a ring-shaped tin rod found in Sweden, dated to Bronze Age period V, has a lead content of about $0.6 \%$ and with an isotopic range argued to be consistent with Cornwall (Ling et al., 2014).

While similarly high lead contents do not seem to be bolstered by more recent analyses of Cornish tin ingots (Wang et al., 2016), this raises the possibility that the lead in the Danish samples was associated with the tin and not only with the copper component. We consider alloying with tin with a high degree of lead to be a possible interpretation for several bronzes from period V (\#\#533, 536 and 634) and VI

(\#645). There is also the possibility that lead was intentionally added, as noted in previous analyses of Danish Late Bronze Age finds (Liversage, 2000:80-84), or that extra lead may have come from cosmelting of copper and galena ores, which is feasible for both Wales and southwest Spain (cf. Northover, 1982; O'Brien, 2015:80). While Great Orme is a possible scenario for \#536, the antimony levels of three of other objects (0.45 to $2.16 \%$ ) are well outside the Great Orme range (below $0.1 \%$ ), and there is hardly any evidence for mining during this period. ${ }^{3}$

On the grounds of the above, several bronzes dated to period V (\#\#532-533, 536, 631-634) and one from VI (\#645) may be attributed to ore sources in the Inn valley in North Tyrol, Austria. The outstanding LI of \#537, a wire from Flø, suggests an origin from Mitterberg copper. The torcs from Antvortskov (\#646-647) have LI compositions fully consistent with ores from the region of Huelva in southern Spain, where at that time local tin was used quite freely. The Pb content in these bronzes (c. $0.3 \%$ and $0.5 \%$ ) is in keeping with bronze compositions occurring in Spain. Another three artefacts of quite varied elemental compositions are consistent with LI ratios of ores from south Spain (\#\#534, 651 and 642). Finally, five bronzes from period VI (\#\#643, 644, 648, 649, 650) and one from period V (\#535) form a tight grouping and seem to be consistent with the ores in Cevennes in Massif Central, France. These are mostly made from fahlores and are low in tin, but four have $\mathrm{Pb}$ at c. $1-5 \%$.

However, there is currently little information about exploitation of these ores in the mid $1^{\text {st }}$ millennium BCE (O’Brien, 2015:105).

When it comes to the question of singular origins for metal within hoards, a common origin from copper ores in North Tyrol, perhaps mixed with high-lead tin may be argued for when it comes to most items from Lysemosegård and Flø. For Antvortskov, a possible interpretation is a binary pattern with two different sources of metal: a fahlore source potentially located in Massif Central and a Cusulphide ore source in Huelva. It is however difficult to determine whether the lines observed in the plots indicate mixing of metals from the above-mentioned sources, or singular sources to groups of metal.

\section{Discussion of key results and culture historical implications}

\subsection{General trends}

Bronze Age Denmark is exceptionally rich in deposited metal and had a high degree of local production already c. 2000 BCE (Vandkilde, 1996: Fig. 266). We can deduce from archaeological findings that annual import of metal was high especially from c. 1500 BCE onwards, and would have demanded regular, well-organized trade caravans (Kristiansen and Suchowska-Ducke, 2015). Our analyses indicate that there were multiple origins for the copper utilized during this long time span,

\footnotetext{
${ }^{3}$ It is, however, worth noticing that the LI compositions are practically identical to a group of British Late Bronze Age objects dated to c. 1200-800 BCE (OXALID).
} 
and several shifts in the supply of copper related to chronology (Fig. 6). Typically, individual samples can be grouped together into populations, which either share similar characteristics or belong to the same assemblage. Some samples are 'outliers' on the basis of unusual chemistry and/or lead isotope compositions. Overall, there seem to be a high level of importation and high replacement rates for metal throughout the Bronze Age. Major trends imply a shift from fahlores around $1600 \mathrm{BCE}$ to a general use of chalcopyrite and oxidized ores. Next major shift coincides with the transition from the Early to the Late Bronze Age in the north c. 1100 BCE, when chalcopyrite ores were replaced by fahlores and ores that are low in impurities.

These general trends are in many respects similar to the recently presented Swedish data-set (Ling et al., 2013; 2014), but certain discrepancies may also be noted; e.g. a more limited range in compositional variation for the Danish set of samples. Neither the really pure bronzes, nor those with elevated contents of e.g. fahlore-indicative elements like $\mathrm{Sb}$, As and $\mathrm{Ag}$ are present in the Danish dataset. Also, the provenance ascriptions of the current study diverge somehow from the Swedish study. Ling and co-authors (2014) traced the origin of the copper arriving in Sweden to mainly three regions, in order of magnitude: the Iberian Peninsula (Spain), Sardinia and the Austrian Alps. Thanks to access to new reference data, we suggest here that the British Isles and the Italian eastern Alps are other strong candidates to much of the copper arriving in Scandinavia c. 1600-900 BCE.

\subsection{Major copper suppliers to Scandinavia}

The current study confirms that metals reached Denmark from a wide range of sources and not primarily from the Alpine or Carpathian copper regions. From c. 2000-1600 BCE, copper smelted from fahlores is significant in the Danish data-set, tentatively interpreted as deriving from the British Isles and the Austrian Alps. In period Ia and continuing into period Ib, the copper can be convincingly matched with ore sources in Spania Dolina, Slovakia. Starting from period Ib, most of the analytical data is consistent with copper from the Great Orme mine in Wales. A comparison of the LI ratios of the Danish bronzes dated to c. 1500-900 BCE with the data for copper ores from the Austrian Alps and Slovak Carpathians shows that there is a considerable group of bronzes with ${ }^{206} \mathrm{~Pb} /{ }^{204} \mathrm{~Pb}<18.3$ that are definitely not consistent with these ores. Instead, the bulk of analysed Danish bronzes from this timespan have lead isotope ratios falling quite convincingly with copper ores from the Italian eastern Alps and, less so, Southern Iberia (Fig. 6).

Beginning around $1600 \mathrm{BCE}$, a substantial influx of copper with As and $\mathrm{Ni}$ as main impurities is seen. While Mitterberg previously was considered a strong candidate for the so-called AsNi-metal, in the Swedish study ores on the Iberian Peninsula were considered more likely sources (Ling et al., 2014). In the current study, the provenance ascriptions have been further differentiated, suggesting on the basis of $\mathrm{Pb}$ isotope matching that mines in the British Isles and the Italian eastern Alps were also likely to have supplied AsNi metal to Denmark. The discrepancy compared to the Swedish study may in part be assigned to access to new ore reference data from the Italians Alps that was not available until very recently. Furthermore, since the LI for the bulk of the Danish artefacts are not compatible with the Mitterberg ores, the previous hypothesis about Mitterberg as one of the major suppliers of copper to Scandinavia must consequently be revised. A recent comprehensive analytical programme shows that Mitterberg has a distinguishable ore signature when isotopes and chemistry are viewed in combination (Pernicka et al., 2016:36). However, only a small percentage of the available data from Scandinavia matches Mitterberg isotopically (Pernicka et al., 2016:39). Looking at the wider picture and archaeological patterns, it seems likely that the domination of the AsNi-metal in periods Ib-III is more likely to be the result of a common period-specific preference for certain ore types and smelting recipes among the Bronze Age metalworkers, than an origin from one single common ore source. This concurs with shifts observed in the Bronze Age usages of different ore types through time, assumed to relate to technological developments (e.g. Merkl, 2010).

\subsection{British Isles: 1600-1300 BCE}

Altogether $16.3 \%$ of the analysed artefacts have been attributed to ore sources in the British Isles. The British Isles is a close neighbour and a likely source of copper and tin to Scandinavia. A recent 
evaluation of Bronze Age copper mining in Britain and Ireland (O'Brien, 2015:154) concluded that after $1500 \mathrm{BCE}$ the only copper producing mine was the Great Orme in Wales. Copper production at the Great Orme started around $1750 \mathrm{BCE}$, and with total output estimates ranging up to c. 1800 tons, this mine was a substantial producer. New chemical and isotopic data on ores from Great Orme (Williams, 2014, 2015, 2017) suggest that this mine is a plausible source for some of the copper arriving in Denmark c. 1600-1300 BCE. For decades it was claimed that the Great Orme could only produce low impurity metal (Ixer and Budd, 1998:26; Northover, 1999:223; O'Brien 2015:150) and not an AsNi type metal. It is only recently that it has been demonstrated that the Great Orme copper ores worked in the Bronze Age were oxidized malachite-goethite ores (with only traces of residual copper sulphide - chalcopyrite) and that these typically contained significant levels of $\mathrm{Ni}$ and As with low $\mathrm{Sb}$, which smelting experiments show transfer into the metal with high partition levels. The AsNi metal type produced dominated the Acton Park metalwork with a significant contribution to the chronological metalwork phases on each side (Williams, 2015, 2017, forthcoming; cf. Northover, 1982). The here suggested link to Great Orme for several period Ib and II objects is indeed interesting and this must be explored further in future studies. Strong evidence is emerging of Great Orme metal reaching several countries in the near Continent, not only based on chemical and isotopic analyses but also combined with typological evidence (e.g. shield pattern palstaves) (Williams, forthcoming). Alderley Edge is another possibility isotopically and whose ore chemistry should be investigated. However, current dating evidence suggests this mine was working in the $19^{\text {th }}$ century BCE but had closed by 1700 BCE and was probably a relatively small mine (O'Brien, 2015:151).

\subsection{Italian Alps: 1500-900 BCE}

Altogether $40.8 \%$ of the analysed artefacts have been attributed to ore sources in the Italian eastern Alps The Italian eastern Alps has not previously figured as a potential source of metal to Scandinavia. The exploitation of copper ores in the Italian eastern Alps in prehistory is well-known thanks to the large amount of archaeological evidence, especially the huge quantities of slags and numerous smelting sites found in the area. Considering the age of the smelting sites, two main peaks of activity have been identified: the first during the Late Chalcolithic (2500-2200 BCE) and beginning of the Early Bronze Age (2200-1650/1600 BCE) and the second during the Italian Recent and Final Bronze Age (1350/1300-950 BCE) (Addis et al., 2016; Angelini et al., 2013; Cierny, 2008; Marzatico, 1997, 2000; Weisgerber and Goldenberg, 2004). Recent analysis of objects dated to these chronological periods and found in northern Italy, proves that metal came from the southeastern Alpine deposits (Angelini et al., 2015; Artioli et al., 2016 with references; Canovaro, 2015). While there is to date no secure evidence of Middle Bronze Age (1650/1600-1350/1300 BCE) smelting activities, metal analysis indicates continuous production of copper in the southeastern Alps (Angelini, in press; Artioli et al., 2016).

Recent works report and discuss the geochemical and isotopic characterization of copper ore deposits in the Italian eastern Alps, focusing on the utility of these data in provenance studies (Artioli et al., 2016; Nimis et al., 2012). The LI data allow for a discrimination of the southeastern Alpine ores from the majority of other European and Mediterranean copper mineralizations. Only a few mineral districts partially overlap with the two main ore fields of the Italian eastern Alps (Artioli et al., 2016):

- Some Austrian chalcopyrite-based ores from Carinthia, Salzburg and Styria overlap with the Valsugana VMS field, but to date there is no evidence that these ores were exploited in prehistory;

- Ores from the Apuane Alps (Northern Tuscany, Italy) overlap with the South Alpine AATV. Again, no mining activities or ancient copper metallurgy is known in the Apuane Alps;

- Two of the four main mineral districts of Sardinia partially overlap with the southeastern Alpine ores: ores from southwest Sardinia (Iglesiente area) overlap with the Valsugana VMS and central Sardinian ores (Barbagia, Sulcis, Ogliastra) with the South Alpine AATV. However, the majority of Sardinian ores have lower ${ }^{208} \mathrm{~Pb} /{ }^{204} \mathrm{~Pb}$ ratios, so in most of cases they can be discriminated. 
The only LI that cannot be clearly distinguished from the Italian eastern Alpine deposits come from ores in Andalusia and in the Alcudia Valley in Spain.

When it comes to elemental compositions, arsenopyrite occurs in the Valsugana VMS, whereas minor amounts of $\mathrm{Pb}, \mathrm{Zn}, \mathrm{Co}, \mathrm{Ni}, \mathrm{As}, \mathrm{Sb}, \mathrm{Bi}$ sulphide and sulphosalts are reported from some of the South Alpine AATV deposits (Artioli et al., 2016). The presence of low levels of As in metalwork from the Italian eastern Alps is therefore reasonable. Except for the sulphide and sulphosalt ores mentioned above, Ni-bearing minerals do not seem to characterize the southeastern Alpine mining region (Artioli et al., 2016). Interestingly, traces of $\mathrm{Ni}(0-0.50 \%)$ and $\mathrm{As}(0-0.50 \%)$ are observed in numerous objects which are chemically and isotopically consistent with a southeastern Alpine origin (Angelini, in press; Angelini et al., 2015; Canovaro, 2015). Thus, the presence of Ni and As in metal from the area, at levels consistent with the AsNi metal seems plausible.

\subsection{Extended circulation time 1300-1100 BCE?}

It has been discussed whether there was a more or less continuous influx of new metals and/or alloys to Scandinavia, or if extensive re-melting should be considered as an alternative, as suggested by e.g. Peter Bray and Mark Pollard (2012). If there was a general re-melting from period II to III (both periods characterised by AsNi-copper) from the same bulk, according to their opinion one would expect an enrichment of $\mathrm{Ni}$ and a concomitant depletion of As due to different behavior of these elements - i.e. vaporization of As. However, this is not the case in the current set of samples (cf. Fig. 8). The minor LI discrepancies noted between period II and III cannot be used to conclusively argue whether or not remelting was important since such minor differences could also indicate that the same, or similar, ore sources were mined during both period II and III.

Nonetheless, the theory of re-melting does seem to find support in archaeological data from Denmark. Use-wear analysis of Early Bronze Age swords demonstrate that period II represented a highpoint in the supply of bronze since a major part of the swords deposited in burials were unused, freshly cast swords with no or very little use-wear (Kristiansen, 1978: Figs. 2-3, 1984; Kristiansen and Suchowska-Ducke, 2015). During period III a major change could be observed: with a significant increase in heavily worn swords. Remarkably, these swords are worn to a degree never seen before or after (Kristiansen and Suchowska-Ducke, 2015: Fig. 12). The conclusion seems clear: sometime during period III metal supplies were cut off for a longer period of time. We can deduce from this that a temporary stop in supplies, due to warfare or other disruptions, as it happened in Europe during the 1300 s and $1200 \mathrm{~s}$ BCE would be felt in increased circulation time, and a potentially a higher frequency of re-melting. However, as long as supplies came from the same or similar mining areas, the chemical and LI signatures would have remained rather constant.

\subsection{A return to fahlores $700-500 \mathrm{BCE}$}

Alone on the basis of evidence from use-wear patterns and the many rich depositions of metalwork, a new source of supply is to be expected from period V (Kristiansen, 1978). During periods V-VI metal signatures quite different from those in periods Ib-III are observed, and it seems that once again, mines utilizing fahlores were dominant suppliers of copper to Denmark. According to Liversage the NS metal, a fahlore characterized by $\mathrm{Sb}>\mathrm{As}$ was paramount in this period and had a far wider spatial distribution in Europe than any earlier used metal type and with particular concentrations in Switzerland, France and Britain. Hypothetical provenance ascriptions have included the Rhone valley, Mitterberg, Kelchalm and Schwaz-Brixlegg in Austria (Liversage, 2000:83-84). The re-introduction of fahlore copper to Denmark in period IV, as was demonstrated by Liversage (2000:33, 39-45), is not evident in the current, more limited, dataset; however, this shift is clearly seen in periods V-VI.

The Late Bronze Age witnessed a substantial influx to Scandinavia of fahlore copper. When viewed in a combined geochemical-isotopic perspective, it is, however, not easy to unequivocally target the sources of copper. Potentially, elevated lead contents may be explained through alloying with $\mathrm{Pb}$-rich tin. Another potential source of lead is $\mathrm{Pb}$-rich copper ores or co-smelting with galena. It is indicated here that the metal came from several provenance areas, including sources in the Austrian eastern 
Alps, France and Southern Iberia. Apart from the suggested continuation in influx of AsNi copper from Italian and Iberian ore sources in period IV, our conclusions regarding the origin of the copper do not diverge substantially from previous conclusions. In this regard, it is striking that an intentional mixing of fahlore copper with low-impurity copper is launched as a possible explanation to account for mixed impurity patterns observed in objects from the Alpine region during the same time span (Pernicka et al., 2016:33-34). Besides, one cannot exclude that metals have been recycled to produce new artefacts.

\section{Denmark and the copper trade networks}

Recent studies have accentuated the high degree of connectivity that characterized the Scandinavian Bronze Age (e.g. Kristiansen and Larsson, 2005; Vandkilde, 2016). Evidence of far-reaching contacts is prominently represented by luxury items like beads of Baltic amber (Angelini and Bellintani, 2005, 2017; Jensen, 2000; Kaul, 2013; Mukherjee et al., 2008; Murillo-Barroso and Martinón-Torres, 2012), Middle Eastern glass beads (Varberg et al., 2015, 2016), and a wider range of items and materials traded between Northern Europe and the Mediterranean (Sabatini and Melheim, 2017).

The current study supports some of the trends previously noted for interaction between Denmark and main copper producing areas in Europe, while also adding information about other potential trade partners previously not accentuated. Especially, this regards the here established connections to the Italian eastern Alps and the western Mediterranean region. During the timespan 2000-1600 BC trade routes were established between southern Scandinavia (Scania and Denmark) and Únětice core areas (including the Carpathian Basin and the Austrian Alps), as well as the British Isles (Vandkilde, 2017). Scandinavian participation in maritime Atlantic networks (Earle et al., 2015; Ling et al., 2014; Vandkilde, 2014) is well established, and the identification in this paper of copper coming into Denmark from Wales 1600-1300 BCE is a further indication of this link.

The shift to AsNi metal c. 1600 BCE coincides with the rise of the Nordic Bronze Age. This particular symbolical universe has been argued to arise in interaction with a Central European axis connecting Scandinavia to the Mediterranean, and perhaps to dramatic events in the wake of the Thera volcanic eruption (Vandkilde, 2014). Interaction between Italy and Scandinavia was argued for on the basis of typology at an early stage in the history of archaeology (e.g. Montelius, 1917:29). This connection is strengthened by the newly presented evidence of bead exchange (Kaul, 2018). A noted influx of Baltic amber (succinate) in northern Italy towards the end of the Middle Bronze Age (Angelini and Bellantini, 2005, 2017), coincides with the here assumed importation of Italian copper to Denmark. During period III, trade networks between Denmark and south Germany, which had dominated during period II, seem to terminate (Kristiansen and Suchowska-Ducke, 2015: Figs. 1 and 4). A new trade and travel network emerged with south-east Central Europe and the Carpathians (Kristiansen and Suchowska-Ducke, 2015: Fig. 6), which continued during period IV (Kristiansen, 1998: Figs. 42-45). Obvious in the current data-set are the consequences of the calamities occurring in Europe in the $14^{\text {th }}$ and $13^{\text {th }}$ centuries BCE. Judging from the heavy worn weaponry found in Denmark, less metal was available. As may be inferred not so much from this study, but previous analyses of Danish metalwork, a shift c. 1100-900 BC back to fahlores represents another major period of change in the Nordic region; the transition between the Early and the Late Bronze Age. Resumed trade relations in period V with southwest Central Europe (Kristiansen, 1978: Fig. 5, 1998: Figs. 82-84), may find support in the here suggested influx of copper from North Tyrol, France and southern Iberia. Again, Britain may have played a prominent role as a trade partner and deliverer of tin, which may again explain the above-mentioned distribution patterns for the NS fahlore copper.

\section{Conclusion}

Along with the provenance study carried out by Ling et al. (2014) this study challenges established 'truths' about dominant copper suppliers to Scandinavia in the Bronze Age. Several important hypotheses regarding the origin of the copper in Denmark have been launched, which needs to be further backed up with more targeted archaeological analysis of certain periods and areas. It is, however, striking how the changes in metal supplies to Denmark seem to coincide with other 
processes of profound cultural change. Notably, this has been demonstrated to be the case c. 1600 $\mathrm{BCE}$ and $1100 \mathrm{BCE}$. Little evidence of re-melting is indicative of high replacement rates for metal in the Early Bronze Age, with a possible exception for period III. Future studies will include the rate of use wear/circulation time on swords and ornaments, period by period, and the number of Bronze Age households/farms in Denmark, from which we can deduce the minimum stock of bronze in use. In the near future, more data will be added to this research, in order to further nuance and broaden the picture.

\section{ACKNOWLEDGEMENTS}

The research leading to these results has received funding from the European Research Council under the European Union's Seventh Framework Programme (FP/2007-2013) / ERC Grant Agreement n. 269442 - THE RISE and from Stiftelsen Riksbankens Jubileumsfond (P14-0308:1) -

SCANDINAVIA'S ROLE. We are grateful to Peter Northover for allowing us to reuse analyses and samples, and to Florence Cattin, Anna Addis, Gilberto Artioli and William O'Brien for discussions and for providing us with reference data.

\section{REFERENCES}

Addis, A. 2013. Late Bronze Age Metallurgy in the Italian Eastern Alps: copper smelting slags and mine exploitation. $\mathrm{PhD}$ dissertation, University of Padua.

Addis A., Angelini, I., Nimis, P., Artioli, G. 2016. Late Bronze Age copper smelting slags from Luserna (Trentino, Italy): interpretation of the metallurgical process. Archaeometry (58), 96-114.

Andras, P., Chovan, M., Dirner, V., Kral, J., Bachlinski, R. 2010. Pb-isotope study in Sbmineralisation from Western Carpathian (Slovakia). Carpathian Journal of Earth and Environmental Sciences 5 (2), 71-80.

Angelini A., Angelini, I., Artioli, G., Nimis, P., Villa, I. 2015. Tipologia e archeometria dei bronzi di Castel de Pedena (San Gregorio nelle Alpi, Belluno), in Leonardi, G., Tinè, V. (Eds.), Preistoria e Protostoria del Veneto. Studi di Preistoria e Protostoria 2. Grafiche Antiga, Crocetta del Montello (TV), Italy, pp. 881-866.

Angelini, I., in press. Archaeometric investigation of swords from Olmo di Nogara (North, Italy) compared with the available data for coeval weapons. In Warfare and Aristocracy in Bronze Age Italy. BAR International Series, Archaeopress.

Angelini, I., Artioli, G., Pedrotti, A., Tecchiati, U. 2013. La metallurgia dell'età del Rame dell'Italia settentrionale con particolare riferimento al Trentino e all'Alto Adige. Le risorse minerarie e i processi di produzione del metallo, in De Marinis, R.C. (Ed.), L'età del Rame: la Pianura Padana e le Alpi al tempo di Ötzi. Compagnia della Stampa Massetti Rodella editori, Brescia, pp. 101-116.

Angelini, I., Bellintani, P. 2005. Archaeological ambers from Northern Italy: An FTIR-DRIFT study of provenance by comparison with the geological amber database. Archaeometry 47 (2), 441-454.

Angelini, I., Bellintani, P. 2017. The use of different amber sources in Italy during the Bronze Age: New archaeometric data. Archaeological and Anthropological Science 9 (4), 673-684.

Albarède, F., Desaulty, A.-M., Blichert-Toft, J. 2012. A geological perspective on the use of $\mathrm{Pb}$ isotopes in archaeometry. Archaeometry 54 (5), 853-867.

Alm, E., Kumpulainen, R., Sundblad, K. 1997. Mesoproterozoic Sediment-hosted Strata-bound Copper Deposits in the Dal Group, Sweden, in Charlet, J.-M. (Ed.), International Cornet Symposium: "Strata-bound Copper Deposits and Associated Mineralizations". Proceedings. Royal Academy of Overseas Sciences, Belgium, pp. 217-243. 
Arribas, A. jr., Tosdal, R.M. 1994. Isotopic composition of Pb in ore deposits of the Betic Cordillera, Spain: origin and relationship to other European deposits. Economic Geology 89, 1074-93.

Artioli, G., Angelini, I., Nimis, P., Addis, A., Villa, I.M. 2014. Prehistoric copper metallurgy in the Italian Eastern Alps: recent results. Historical metallurgy 47 (2013), 51-59.

Artioli G., Angelini, I., Nimis, P., Villa, I.M. 2016. A lead-isotope database of copper ores from the Southeastern Alps: A tool for the investigation of prehistoric copper metallurgy. Journal of Archaeological Science 2016 (75), 27-39.

Baron, S., Carignan, J., Laurent, S., Ploquin, A. 2006. Medieval lead making on Mont-Lozère Massif (Cévennes-France): Tracing ore sources using Pb isotopes. Applied Geochemistry 21 (2006), 241-252.

Baron, S., Tămaş, C.G., Cauuet, B. and Munoz, M. 2011. Lead isotope analyses of gold-silver ores from Roşia Montană (Romania): a first step of metal provenance study of Roman mining activity in Alburnus Maior (Roman Dacia). Journal of Archaeological Science 38, 1090-1100.

Baron, S., Tămaş, C.G., Le Carlier, C. 2013. How mineralogy and geochemistry can improve the significance of $\mathrm{Pb}$ isotopes in metal provenance studies. Archaeometry 56, 4 (2014), 665-680.

Bielicki K.H., Tischendorf, G. 1990. Lead isotope and $\mathrm{Pb}-\mathrm{Pb}$ model age determinations of ores from Central Europe and their metallogenetic interpretation. Contrib. Mineral. Petrol. 106, 440-461.

Brevart, O., Dupré, B., Allegre, C.J. 1982. Metallogenic provinces and the remobilization process studied by lead isotopes: lead-zinc ore deposits from the Southern Massif Central, France. Econ. Geol. $77,564-575$.

Begemann, F., Schmitt-Strecker, S., Pernicka, E., Lo Schiavo, F. 2001. Chemical composition and lead isotopy of copper and bronze from Nuragic Sardinia. European Journal of Archaeology 4, 43 85 .

Bray, P.J., Pollard, A.M. 2012. A new interpretative approach to the chemistry of copper-alloy objects: source, recycling and technology. Antiquity 86, 853-867.

Bunnefeld, J-H. 2016. Älterbronzezeitliche Vollgriffschwerter in Dänemark und Schleswig-Holstein. Studien zu Form, Verzierung, Technik und Funktion. Teil I : Text und Katalog. Wachholtz Murmann Publishers, Mainz.

Canovaro, C. 2015. Mining and diffusion of Alpine copper in Friuli Venezia Giulia in the Bronze Age. $\mathrm{PhD}$ dissertation, University of Padua.

Cullberg, C. 1968. On Artifact Analysis. A study in the systematics and classification of a Scandinavian Early Bronze Age material with metal analysis and chronology as contributing factors. Acta Archaeologica Lundensia. Series in $4^{\circ}$ No. 7. Lund.

Cierny J. 2008. Prähistorische Kupferproduktion in den südlichen Alpen: region Trentino Orientale. Der Anschnitt Beiheft 22. Bergbau-Museum, Bochum.

Earle, T., Ling, J., Uhnér, C. O. J. Stos-Gale, Z., Melheim, L. 2015. The Political Economy and Metal Trade in Bronze Age Europe: Understanding Regional Variability in Terms of Comparative Advantages and Articulations. European Journal of Archaeology 18 (4), 633-657. 
Gale, N. 2001. Archaeology, science-based archaeology and the Mediterranean Bronze Age metals trade: a contribution to the debate. European Journal of Archaeology 4 (1), 113-130.

Gale, N.H., Stos-Gale, Z.A., Maliotis, G., Annetts, N. 1997. Lead isotope data from the Isotrace Laboratory, Oxford: Archaeometry data base 4, ores from Cyprus. Archaeometry 39 (1), 237-246.

Grenne, T., Ihlen, P.M., Vokes, F.M. 1999. Scandinavian Caledonide metallogeny in a plate tectonic perspective. Mineralium Deposita 34, 422-471.

Hauptmann, A. 2009. Lead Isotope Analysis and the Origin of Sardinian Metal Objects, in LoSciavo, F., Muhly, J.D., Maddin, R., Giumlia-Mair, A. (Eds.), Oxhide Ingots in the Central Mediterranean, CNR - Istituto di studi sulle civiltà dell’Egeo e del vicino Oriente, Roma, pp. 494-509.

Höppner, B., Bartelheim, M., Husijmans, M., Krauss, R., Martinek, K., Pernicka, E., Schwab, R. 2005. Prehistoric copper production in the Inn Valley, Austria, and the earliest copper production in Central Europe. Archaeometry 47 (2), 293-315.

Huelga-Suarez, G., Moldovan, M., Suarez Fernandez, M., De Blas Cortina, M.A., Vanhaecke, F., Garcia Alonso, J.I. 2011: Lead isotopic analysis of copper ores from the Sierra El Aramo (Asturias-Spain). Archaeometry 54 (2), 685-697.

Huelga-Suarez, G., Moldovan, M., Suarez Fernandez, M., De Blas Cortina, M.A., Garcia Alonso, J.I. 2012: Defining the lead isotope fingerprint of copper ores from north-west Spain: the El Milagro mine (Asturias). Archaeometry 56 (1), 88-101.

Huelga-Suarez, G., Moldovan, M., Suarez Fernandez, M., De Blas Cortina, M.A., Garcia Alonso, J.I. 2013. Isotopic composition of lead in copper ores and a copper artefact from the LA Profunda mine (Leon, Spain). Archaeometry 56 (4), 651-664.

de Ignacio, C., Muñoz, M., Sagredo, J., Fernández-Santín, S., Johansson, Å. 2006. Isotope geochemistry and FOZO mantle component of the alkaline-carbonatitic association of Fuerteventura, Canary Islands, Spain. Chemical Geology 232, 99-113.

Ixer, R.A., P. Budd 1998. The Mineralogy of Bronze Age Copper Ores from the British Isles: Implications for the Composition of Early Metalwork. Oxford Journal of Archaeology 17, 15-41.

Jensen, J. 2000. Rav. Nordens guld. Gyldendal, København.

Junghans, S., Sangmeister, E., Schröder, M. 1968. Kupfer und Bronze in der frühen Metallzeit Europas. Katalog der Analysen Nr. 985-10040. Studien zu den Anfängen der Metallurgie. RömischGermanisches Zentralmuseum. Band 2, teil 3. Mann Verlag, Berlin.

Junghans, S., Sangmeister, E., Schröder, M. 1974. Kupfer und Bronze in der frühen Metallzeit Europas. Katalog der Analysen Nr. 10041-22000. Studien zu den Anfängen der Metallurgie. RömischGermanisches Zentralmuseum. Band 2, teil 4. Mann Verlag, Berlin.

Kaul, F., 2013. The Nordic razor and the Mycenaean lifestyle. Antiquity 87, 461-472.

Kaul, F. 2018. Gennem europæiske landskaber. Bronzealderens vidtstrakte forbindelser - og hvordan var de mulige?, in Boddum, S., Mikkelsen, M., Terkildsen, N. (Eds.), Status og samfundsstruktur i yngre bronzealders lokale kulturlandskab. Yngre bronzealders kulturlandskap vol. 6. Viborg and Holsterbro, 
Klassen, L. 2000. Frühes Kupfer im Norden. Untersuchungen zu Chronologie, Herkunft und Bedeutung der Kupferfunde der Nordgruppe der Trichterbecherkultur. Jysk Arkæologisk Selskab, Moesgård Museum.

Klassen, L., Stürup, S. 2001. Decoding the Riesebusch-copper: Lead-Isotope Analysis applied to Early Neolithic Copper Finds from South Scandinavia. Praehistorische Zeitschrift 76 (1), 55-73.

Klein, S., Domergue, C., Lahaye, Y., Brey, G.P., von Kaenel, H.-M. 2009. The lead and copper isotopic composition of copper ores from the Sierra Morena (Spain). Journal of Iberian Geology 35 (1), 59-68.

Köppel, V., Schroll, E. 1983. Lead isotopes of Palaeozoic, strata-bound to stratiform galena bearing sulfide deposits of the Eastern Alps (Austria): implications for their geotectonic setting. Schweiz Mineral. Petrogr. Mitt. 63, 347-360.

Krause, R. 2003. Studien zur kupfer- und frühbronzezeitlichen Metallurgie Zwischen Karpatenbecken und Ostsee. Verlag Marie Leidorf GmbH, Rahden/Westfalen.

Kresten, P. 2005: Analysis of LBA celts from the collections of the Museum of Nordic Antiquities, Uppsala University, in Forenius, S. (Ed.), Project "Iron technology - a successful innovation. From bronze to iron in Scandinavia and Greece". Activity Report 2000-2001. Geoarchaeological Laboratory, UV GAL, Department of Archaeological Excavations, National Heritage board. Uppsala, pp. 36-48.

Kristiansen, K. 1978. The consumption of wealth in Bronze Age Denmark. A study of the dynamics of economic process in tribal societies, in Kristiansen, $\mathrm{K}$ and Paludan-Müller, C. (Eds.), New Directions in Scandinavian Archaeology. Studies in Scandinavian Prehistory and Early History 1. Copenhagen, pp. 158-190.

Kristiansen, K. 1998. Europe Before History. New studies in archaeology. Cambridge University Press, Cambridge.

Kristiansen 2013 [online]. The Rise. Travels, transmissions and transformations in temperate northern Europe during the 3rd and 2nd millennium BC: the rise of Bronze Age societies. URL: http://therise.sel

Kristiansen, K., Larsson, T.B. 2005. The Rise of Bronze Age Society. Travels, Transmissions and Transformations. Cambridge University Press, Cambridge.

Kristiansen K., Suchowska-Ducke, P. 2015. Connected Histories: the Dynamics of Bronze Age Interaction and Trade 1500-1100 BC, Proceedings of the Prehistoric Society 81, 361-392.

Kušik, D. 2015. History of mining at the Territory of Slovakia. Slovak Geological Magazine 15(2), 520.

Le Guen, M., Orgeval, J-J., Lancelot, J. 1991. Lead isotope behaviour in a polyphased $\mathrm{Pb}-\mathrm{Zn}$ ore deposit: Les Malines (Cevennes, France). Mineral Deposits 26, 180-188.

Ling, J., Hjärthner-Holdar, E., Grandin, L., Billström, K., Persson, P-O. 2013. Moving metals or indigenous mining? Provenancing Scandinavian Bronze Age artefacts by lead isotopes and trace elements. Journal of Archaeological Science 40 (2013), 291-304. 
Ling J., Stos-Gale, Z., Grandin, L., Billström, K., Hjärthner-Holdar, E., Persson, P-O. 2014. Moving metals II: Provenancing Scandinavian Bronze Age artefacts by lead isotope and elemental analyses. Journal of Archaeological Science 41 (1), 106-132.

Liversage, D. 1994. Interpreting Composition Patterns in Ancient Bronze: the Carpathian Basin. Acta Archaeologica 65(1994), 57-134.

Liversage, D. 2000. Interpreting Impurity Patterns in Ancient Bronze: Denmark. Det kongelige nordiske oldskriftselskab, København.

Liversage, D., Northover, J.P. 1998. Prehistoric trade monopolies and bronze supply in northern Europe, in Mordant, C., Pernot, M., Rychner, V. (Eds.), L'atelier du bronzier en Europe du XXe au VIIIe siècle avant notre ère. Actes du colloque international "Bronze -96" Neuchâtel et Dijon, $1996 \mathrm{I}$. Paris, pp. 137-151.

Marcoux, E. 1998. Lead isotope systematics of the giant massive sulphide deposits in the Iberian Pyrite belt. Mineral. Deposita 33, 45-58.

Marcoux, E., Grancea, L., Lupulescu, M., Milesi, J-P. 2002. Lead isotope signatures of epithermal and porphyry-type ore deposits from Romanian Carpathian Mountains. Mineralium Deposita 37, 173-184.

Marzatico, F. 1997. L'industria metallurgica nel Trentino durante l'età del Bronzo, in Bernabò Brea, M., Cardarelli, A., Cremaschi, M. (Eds.), Le Terramare. La Più Antica Civiltà Padana. Electa, Milano, pp. 576-972.

Marzatico F. 2000. L'età del Bronzo Recente e Finale, in Lanziger, M., Marzatico, F., Pedrotti, A. (Eds.), Storia del Trentino, La preistoria e la protostoria. Il mulino 1, pp. 367-416.

McGovern, P.E, Gretchen, R.H., Mirzoian, A. 2013. A biomolecular archaeological approach to 'Nordic grog'. Danish Journal of Archaeology 2 (2), 112-131.

Melheim, L. 2009. Kobberimport eller kobberproduksjon?, in Grønnesby, G., Henriksen, M.M. (Eds.), Det 10. nordiske bronsealdersymposium i Trondheim 5.-8. oktober 2006. Vitark 6. Acta archaeologica Nidrosiensia. Tapir akademisk forlag, Trondheim, pp. 20-35.

Melheim, L. 2015. Recycling Ideas. Bronze Age Metal Production in Southern Norway. BAR International Series 2715. Archaeopress, Oxford.

Melheim, L., Horn, C. 2014. Tales of hoards and swordfighters in Early Bronze Age Scandinavia: the Brand New and the Broken. Norwegian Archaeological Review 47(1), 18-41.

Merkl, M.B. 2010. Bell Beaker Metallurgy and the Emergence of Fahlore-Copper Use in Central Europe. Interdisciplinaria Archaeologica Natural Sciences in Archaeology 1 (1-2), 19-27.

Montelius, O. 1885. Om tidsbestämning inom bronsåldern med särskildt afseende på Scandinavien. Kungl. Vitterhets Historie och Antikvitets Akademiens Handlingar 30 (10). Stockholm.

Montelius, O. 1917. Minnen från vår forntid. Ordnade och beskrifna af Oscar Montelius. Norstedt, Stockholm.

Mukherjee, A.J., Roßberger, E., James, M.A., Pfälzner, P., Higgitt, C.L., White, R., Peggie, D.A., Azar, D., Evershed, R.P. 2008. The Qatna lion: scientific confirmation of Baltic amber in late Bronze Age Syria. Antiquity 82, 49-59. 
Murillo-Baroso, M., Martinón-Torres, M. 2012. Amber Sources and Trade in the Prehistory of the Iberian Peninsula. European Journal of Archaeology 15/2 (2012), 187-216.

Niederschlag E., Pernicka, E., Seifert, T., Bartelheim, M. 2003. The determination of lead isotope ratios by multiple collector ICP-MS: a case study of early Bronze age artefacts and their possible relation with ore deposits of the Erzgebirge. Archaeometry 45, 61-100.

Nimis, P., Omenetto, P., Giunti, I., Artioli, G., Angelini, I. 2012. Lead isotope systematic in hydrothermal sulphide deposits from the central-eastern Southalpine (northern Italy). European Journal of Mineralogy 24, 23-37.

Northover, P. 1982. The Exploration of the Long-Distance Movement of Bronze in the Bronze and early Iron Age Europe. Bulletin of the Institute of Archaeology, University of London 19, 45-72.

Northover, J.P. 1996a. Metal analysis and metallography of early metal objects from Denmark, in From Stone to Bronze. The Metal-work of the Late Neolithic and Earliest Bronze Age in Denmark, Archaeological Society Publications XXXII. Aarhus, pp. 321-358.

Northover, J.P. 1996b. Comparison of metal analyses by different laboratories, in From Stone to Bronze. The Metalwork of the Late Neolithic and Earliest Bronze Age in Denmark. Archaeological Society Publications XXXII. Aarhus, pp. 359-367.

Northover, J.P. 1999. The earliest metalworking in southern Britain. Der Anschnitt 9, 211-225.

Northover, J.P., O‘Brien, W., Stos, Z. 2001. Lead isotopes and metal circulation in Beaker/Early Bronze Age Ireland. Journal of Irish Archaeology 10, 25-47.

O'Brien, W. 2004. Ross Island. Mining, Metal and Society in Early Ireland. Bronze Age Studies 6. Department of Archaeology, National University of Ireland, Galway.

O’Brien, W. 2015. Prehistoric copper mining in Europe. Oxford University Press, Oxford.

Olsen, J., Hornstrup, K.M., Heinemeier, J., Bennike, P., Thrane, H. 2011. Chronology of the Danish Bronze Age based on 14C dating of cremated bone remains. Radiocarbon 53 (2), 261-275.

OXALID. Oxford Archaeological Lead Isotope Database. Isotrace laboratory, Oxford. URL: http://oxalid.arch.ox.ac.uk/

Pernicka, E. 2010. Archäometallurgische Untersuchungen am und zum Hortfund von Nebra. Tagungen des Landesmuseums für Vorgeschischte Halle 05, 719-734.

Pernicka, E., Lutz, J., Stöllner, T. 2016. Bronze Age copper produced at Mitterberg, Austria, and its distribution. Archaeologia Austriaca 100, 19-55.

Pomiès, C., Cocherie, A., Guerrot, C., Marcoux, E., Lancelot, J. 1998. Assessment of the precision and accuracy of lead-isotope ratios measured by TIMS for geochemical applications: example of massive sulphide deposits (Rio Tinto, Spain). Chemical Geology 144, 137-149.

Prange, M., Ambert, P. 2005. Caractérisation géochimique et isotopique des minerais et des métaux base cuivre de Cabrières (Hérault), in Ambert, P., Vaquer., J. (Eds.), La première métallurgie en France et dans les pays limitrophes, [Paris], Soc préhist fr, Actes du colloque international (Carcassonne; 28-30 septembre 2002). Soc préhist fr, mémoire 37, pp. 71-81. 
Prescott, C. 2006. Copper production in Bronze Age Norway?, in Glørstad, H., Skar, B., Skre, D. (Eds.), Historien i forhistorien. Festskrift til Einar Østmo på 60-årsdagen. Skrifter 4. Kulturhistorisk museum, Universitetet i Oslo, pp. 183-190.

Rehren, T., Pernicka, E. 2008. Coins, artefacts and isotopes - archaeometallurgy and archaeometry. Archaeometry 50/2 (2008), 232-248.

Renzi, M., Montero-Ruiz, I., Bode, M. 2009. Non-ferrous metallurgy from the Phoenician site of La Fonteta (Alicante, Spain) a study of provenance. Journal of Archaeological Science 36, 2584-2596.

Rohl, B., Needham, S.P. 1998. The Circulation of Metal in the British Bronze Age: The Application of Lead Isotope Analysis. Occasional Paper 102. British Museum Press.

Sabatini, S., Melheim, L. 2017. Nordic-Mediterranean relations in the second millennium BC, in Bergerbrant, S. and Wessman, A. (Eds.), New Pespectives on the Bronze Age. Proceedings of the 13th Nordic Bronze Age Symposium held in Gothenburg 9th to 13th June 2015. Archaeopress, Oxford, pp. 355-362.

Santos Zalduegui, J. F., García de Madinabeitia, S., Gil Ibarguchi, J. I., Palero, F. 2004. A lead isotope database: The Los Pedroches - Alcudia area (Spain); implications for archaeometallurgical Connections Across southwestern and southeastern Iberia. Archaeometry 46 (4), 625-634.

Schreiner, M. 2007. Erzlagerstätten im Hrontal, Slowakei. Genese und prähistorische Nutzung. Forschungen zur Archäometrie und Altertumwissenschaft. Band 3, VML Verlag. Rahden/Westfalien.

Schroll, E., 1997. Geochemische und geochronologische Daten und Erlauterungen, in Weber, L. (Ed.), Handbuch der Largerstatten der Erze, Industrialminerale und Energierohstoffe Osterreichs. Archiv für Lagerstatten Forschung, band 19. Geologische Bundesanstalt, pp. 395-495.

Schwab, R., Ullén, I., Wunderlich, C-H. 2010. A sword from Vreta Kloster, and black patinated bronze in Early Bronze Age Europe. Journal of Nordic Archaeological Science 17, 27-35.

Stos-Gale, Z.A. 2017. Interpretation of Lead Isotope Results from the Pile hoard, in The Metal Hoard from Pile in Scania, Sweden. Place, things, time, metals, and worlds around 2000 BCE. The Swedish History Museum, Studies 29. Aarhus University Press, pp. 205-212.

Stos-Gale, Z.A., Gale, N.H. 2009. Metal provenancing using isotopes and the Oxford Archaeological lead isotope database (OXALID). Archaeological and Anthropological Science 1 (3), 195-213.

Stos-Gale, Z., Gale, N.H., Houghton, J., Speakman, R. 1995. Lead isotope data from the Isotrace Laboratory, Oxford: Archaeometry data base 1, ores from the Western Mediterranean. Archaeometry 37 (2), 407-415.

Stos-Gale, Z.A., Gale, N.H., Annetts, N. 1996. Lead isotope data from the Isotrace Laboratory, Oxford: archaeometry data base 3, ores from the Aegean, Part I. Archaeometry 38(2), 381-390.

Stos-Gale, Z.A., Maliotis, G., Gale, N.H., Annetts, N. 1997. Lead isotope characteristics of the Cyprus copper ore deposits applied to provenance studies of copper oxhide ingots. Archaeometry 39, 83-123.

Stos-Gale Z.A., Gale, N.H., Annetts, N., Todorov, T., Lilov, P., Raduncheva, A., Panayotov, I. 1998. Lead isotope data from the Isotrace laboratory, Oxford: archaeometry data base 5, ores from Bulgaria. Archaeometry 40, 217-226. 
Thrane, H. 1975. Europaiske forbindelser. Bidrag til studiet af fremmede forbindelser i Danmarks yngre broncealder (periode $I V-V$ ). Nationalmuseet, København.

Tornos, F., Chiaradia, M. 2004. Plumbotectonic evolution of the Ossa Morena Zone, Iberian Peninsula: Tracing the influence of mantle-crust interaction in ore-forming processes. Economic Geology 99, 965-985.

Trincherini, P. R., Barberow, P., Quarati, P., Domergue, C., Long, L. 2001. Where do the lead ingots of the Saintes-Maries-de-la-Mer wreck come from? Archaeology compared with physics.

Archaeometry 43 (3), 393-406.

Vandkilde, H. 1996. From Stone to Bronze. The Metalwork of the Late Neolithic and Earliest Bronze Age in Denmark. Archaeological Society Publications XXXII. Aarhus.

Vandkilde, H. 1998. Denmark and Europe: Typochronology, Metal Composition and Socio-economic Change in the Early Bronze Age, in Mordant, C., Pernot, M., Rychner, V. (Eds.), L'atelier du bronzier en Europe du XXe au VIIIe siècle avant notre ère. Actes du colloque international "Bronze -96" Neuchâtel et Dijon, 1996 I. Paris, pp. 119-135.

Vandkilde, H. 2014. Breakthrough of the Nordic Bronze Age: Transcultural Warriorhood and a Carpathian Crossroad in the Sixteenth Century BCE. European Journal of Archaeology 17 (4), 602633.

Vandkilde, H. 2016. Bronzization. Prähistorische Zeitschrift 91(1), 103-123.

Vandkilde, H. 2017. The Metal Hoard from Pile in Scania, Sweden. Place, things, time, metals, and worlds around 2000 BCE. With contributions by P. Northover, K. Becker and Z. Stos-Gale. The Swedish History Museum, Studies 29. Aarhus University Press.

Vandkilde, H., Rahbek, U., Rasmussen, K.L. 1996. Radiocarbon Dating and the Chronology of Bronze Age Southern Scandinavia, in Randsborg, K. (Ed.), Absolute Chronology. Archaeological Europe 2500-500 BCE. Acta Archaeologica vol. 67. Munksgaard, København, pp. 183-198.

Varberg, J., Gratuze, B., Kaul, F. 2015. Between Egypt, Mesopotamia and Scandinavia: Late Bronze Age glass beads found in Denmark. Journal of Archeological Science 54, 168-181.

Varberg, J., Gratuze, B., Kaul, F., Haslund Hansen, A., Rotea, M., Wittenberger, M. 2016. Mesopotamian glass from Late Bronze Age Egypt, Romania, Germany, and Denmark. Journal of Archaeological Science 74, 184-194.

Wang, Q., Strekopytov, S., Roberts, B.W., Wilkin, N. 2016. Tin ingots from a probable Bronze Age shipwreck off the coast of Salcombe, Devon: Composition and microstructure. Journal of Archaeological Science 67, 80-92.

Weisgerber, G., Goldenberg, G. (Eds.) 2004. Alpenkupfer-Rame Delle Alpi. Der Anschnitt 17. Deutsches Bergbau Museum, Bochum.

Williams, R.A. 2014. Linking Bronze Age copper smelting slags from Pentrwyn on the Great Orme to ore and metal. The origins of metallurgy in Europe. Journ. Historical Metallurgy 47 (1/2013), 93-110.

Williams, R.A. 2015. Where did all the Prehistoric Copper go? Linking the Great Orme ores to Bronze Age metalwork. The Journal of the Great Orme Exploration Society 2015, 1-10. 
Williams, R.A. 2017. The Great Orme Bronze Age copper mine: Linking ores to metals by developing a geochemically and isotopically defined mine-based metal group methodology, in Montero-Ruiz, I., Perea, A. (Eds.), Archaeometallurgy in Europe IV. Bibliotheca Praehistorica Hispana, vol XXXIII. Editorial CSIC, Madrid, pp. 29-47.

Williams, R.A. forthcoming. Characterizing Bronze Age copper from the Great Orme mine in North Wales to determine and interpret its distribution. $\mathrm{PhD}$ dissertation, University of Liverpool.

\section{Captions}

Figure 1: Map of Denmark with find sites indicated. Map by Rich Potter/Archaeodesign.

Figure 2 (2_1): Bar diagram showing the distribution of analyses across periods. (2_2): Images of select objects, a: Late Neolithic II flanged axes from Store Heddinge (after Vandkilde, 1996), b: Bronze Age period Ia flanged axes from Bondesgårde, Torsted (photo National Museum of Denmark, CC BY-SA), c: period Ib shafthole axe from Holtegård (photo Kit Weiss, National Museum of Denmark), d: period Ib metal-hilted swords from Dystrupgård (photo Søren Harbo, Museum Østjylland), e: period II hoard from Vognseup Enge (photo National Museum of Denmark, CC BYSA), f: period III bracelet from Førby (photo Lene Melheim), g: period IV hoard from Kostræde (photo National Museum of Denmark), h: period VI hoard from Antvortskov (photo National Museum of Denmark).

Figure 3 (3_1 and 3_2): Box-whisker plots illustrating the distribution and variation of $\mathrm{Sn}$ and $\mathrm{Pb}$ in relation to chronology. Note the break in Y-axis, and change in scale, to demonstrate the few outliers with unusually high $\mathrm{Pb}$ (in periods II and $\mathrm{VI}$ ).

Figure 4: $\mathrm{Pb}$ isotope diagrams showing data from Danish artefacts. Clusters $\mathrm{A}$ to $\mathrm{D}$ provide a crude basis for differentiating between groups of samples. Data for samples from Røjlemose and Antvortskov tend to fall on straight-lines which are marked with 1-1' and 2-2', respectively.

Figure 5 (5_1 and 5_2): A comparison between $\mathrm{Pb}$ isotope data of artefacts from Sweden (red symbols) and Denmark (black symbols). The data refer to finds from Bronze Age periods I to VI, following the definition of Montelius (1885).

Figure 6: Bar-chart overview of the interpreted provenance areas of the artefacts. Period I has been split into $1 \mathrm{a}$ (four samples) and $1 \mathrm{~b}$ (fourteen samples) Four major provenance areas are outlined, and in addition samples interpreted to derive from less frequent areas are grouped together in the category "Miscellaneous"; the latter is subdivided into France (Fra, six samples), Sardinia (Sar, one sample) and Slovak Carpathians (Slo, eight samples). Lighter colour tints and/or question marks are used to illustrate origins that are less well constrained, see text. The most important sources of reference data used to constrain provenance areas are as follows: Andras et al. (2010), Arribas and Tosdal (1994), Baron et al. (2006; 2011), Bielicki and Tischendorf (1990), Brevart et al. (1982), Begeman et al. (2001), Gale et al. (1997), Huelga-Suarez et al. (2011, 2012, 2013), Klein et al. (2009), Köppel and Schroll (1983), Le Guen et al. (1991), Marcoux (1998), Marcoux et al. (2002), Niederschlag et al. (2003), Nimis et al. (2012), OXALID, Pomiès et al. (1998), Prange and Ambert (2005), Renzi et al. (2009), Rohl and Needham (1998), Santos et al. (2004), Schreiner (2007), Schroll (1997), Stos-Gale et al. (1995, 1996, 1997, 1998), Tornos and Chiaradia (2004), Trincherini et al. (2001) and Williams (2014, 2015).

Figure 7: Concentration of Sb-Ag in the Danish artefacts. Some general patterns in relation to chronology that can be distinguished are schematically indicated, here the high concentrations indicative of fahlores, from LNII and periods V and VI. Also highlighted are the period I samples corresponding to cluster $\mathrm{E}$ in figure 4 . 
Figure 8: Concentration of Ni-As and Ni-Ag in the Danish artefacts. Some general patterns in relation to chronology that can be distinguished are schematically indicated in colours corresponding to symbols for the chronological periods, respectively.

Figure 9: Comparison of LI patterns for the ores from the British, Irish, Slovak and Mitterberg ore deposits with the earliest bronzes from Denmark dated to LN-period Ib. The LI ratios for the Mitterberg and Great Orme mines are highly radiogenic and don't form a cohesive group. In contrast, the ores from Copa Hill and Ross Island follow well the geological age lines.

Figure 10: Comparison of LI data for the earliest bronzes from Denmark using the radiogenic isotopic ratios that are mostly measured with higher accuracy than the ratios to the primeval $204 \mathrm{~Pb}$. This plot shows more clearly the consistency of some of the artefacts with the ores from the Great Orme and Slovakia.

Figure 11: Plot of LI data for the bronzes from Denmark dated to period II compared with the ores from Mitterberg, Slovakia, Great Orme and the western Mediterranean. This plot demonstrates that there is no overlap in the LI ratios for ores from Slovakia and Mitterberg with the western Mediterranean ores. The majority of the data for Mitterberg is outside the range (less than 0.84 for $207 \mathrm{~Pb} / 206 \mathrm{~Pb}$ ) of ratios shown on this plot.

Figure 12: Comparative plot of LI ratios to the 204Pb for bronzes from Denmark dated to periods II and III and the relevant ores. The analyzed bronzes dated to period III show a very tight grouping consistent with ores in the Italian eastern Alps, and to some extent also with the ores from southern Iberia.

Figure 13: LI plot of radiogenic ratios, comparing bronzes dated to periods II, III and IV and the ores. On this plot both the overlap and separation of ores from southern Iberia and the Italian eastern Alps are clearly visible.

Fig. 14: Plot of LI data for bronzes dated to periods V and VI compared with relevant ores. The change in the pattern of LI compared to previous periods is clearly visible.

Table 1: Information about the objects analysed in the current study: identification numbers, chronology, provenance, typology and find circumstances.

Table 2: Chronological overview Nordic Late Neolithic and Bronze Age: chronological ranges, conventional terms and archaeological periods.

SUPPLEMENTARY_Table 1: Analytical results of all analysed objects in the current study. Uncertain provenance ascription are followed by a question mark and discussed further in the text. * EPMA data were obtained by JEOL in the current study, all others are obtained by CAMEBAX (by P. Northover)." with low totals indicates oxidized samples. Some samples are analysed by both instruments (for comparison, see Supplementary table 2). LI: The mass bias correction was made by spiking samples with a thallium solution and normalizing the raw data to a given 203Tl/205Tl ratio. The accuracy and precision of the analyses were monitored by multiple runs of the NIST SRM 981 lead isotope standard and the normalized ratios of the samples were adjusted accordingly. The maximum analytical error (external reproducibility) for $\mathrm{Pb}$ isotope compositions of unknowns reported against $204 \mathrm{~Pb}$ is estimated to be $\pm 0.10 \%$, whereas the estimated errors for ratios reported against $206 \mathrm{~Pb}$ are lower. Appropriate (maximum) external uncertainties are indicated as error bars in the presented $\mathrm{Pb}-\mathrm{Pb}$ isotope diagrams. For details see e.g. de Ignacio et al. (2006). 
SUPPLEMENTARY_Table 2: EPMA of a selection of samples (NMK no) analysed by WDSmethod. First row: analysed by JEOL JXA-8530 F as in the current study. Second row (in bold): previous analyses by CAMEBAX (P. Northover).

Note: the analysed areas are not totally identical. Some samples (e.g. 642, 645 and 650) are extensively corroded (selectively), other contain sulfides that are heterogeneously distributed that might affect the bulk content of S. In some samples there are discrepancies in the content of Sn that cannot be explained $(642,647,657)$. The previous analysis of sample 657 is odd in terms of copper content (and total sum) indicating oxidized areas that cannot be found in the current analyses. Trace elements that are important signatures, as $\mathrm{Ni}, \mathrm{As}, \mathrm{Ag}, \mathrm{Bi}$ and $\mathrm{Sb}$ are in most samples in the same order of magnitude (an exception is sample 659 with discrepancy in Ag, also accompanied with discrepancy in $\mathrm{Sn}$ ). Detection limits from JEOL are generally in the order of c. 0.01 ; for $\mathrm{Bi}, \mathrm{Cu}, \mathrm{Zn}$ in the order of 0.02 and for lead 0.03 . 